\title{
FACTORS AFFECTING THE ACCEPTANCE OF HONEYBEE QUEEN CUPS AND ROYAL JELLY PRODUCTION
}

\author{
A. S. F. Sherif, Marwa B. M. Gomaa and K.I.M. Helaly \\ Plant Protection Research Institute, Agricultural Research Centre, Giza, Egypt.
}

Received: Jun. 4, 2018

Accepted: Jul. 30,2018

\begin{abstract}
Royal jelly is one of the most important honey bee products. it plays vital roles in honeybee biology and in the improvement of human health. Production of royal jelly affecting by many factors. The study aimed to investigate some factors affecting the honeybee queen's acceptance and the amount produce of royal jelly. Effecting of different batches within cub positions during different seasons were studied. The colonies were moved from their original place in the middle of the day to another place away inside the apiary. It was equipped with empty wooden colonies that placed in the places of the original breeding colonies. The highest acceptance percentage mean was $62.7 \pm 5.013 \%$ recorded at third batch. As the lowest percentage mean was $54 \pm 4.855 \%$ recorded at fifth batch, the highest royal jelly quantity mean was $153.5 \pm 5.887 \%$ recorded in third batch. As the lowest percentage mean was $141.2 \pm 6.149$ recorded in fifth batch. The grafted queen cups acceptance percentages mean affecting significant by cups position, different seasons and patches.
\end{abstract}

Key words: Acceptance - royal jelly -cups position -- batches -grafted queen cups

\section{INTRODUCTION}

Royal jelly is standout amongst the most significance items in honey bee products. It created from hypopharyngeal and mandibular glands of 6-12 days old workers, (Deseyn and Billen, 2005 and Hassan and Khater, 2006). Royal jelly is a white creamy substance contains basically of proteins, sugars, and lipids (Schmidt, 1997). Additionally, it has many benefits for humans such as stimulate the immune system, strengthens the body and as a good assistant cure for many diseases such as leukemia, cancer, high blood pressure, high cholesterol, and infertility in males and females (Krell,1996).

Royal jelly contains amazing measures of proteins, lipids, glucides, vitamins, hormones, compounds, and mineral substances (Howe et al., 1985). The arrangement of components in the Royal jelly are water (50 to $60 \%$ ), proteins $(18 \%)$, sugars $(15 \%)$, lipids $(3 \%$ to $6 \%)$, mineral salts $(1.5 \%)$, and vitamins (trace amount) (Nagai and Inoue, 2004). There are a few elements influencing Royal jelly production. The most essential of them are the age of transferred larvae (Sahinler et al., 1997), encouraging (Fuhai et al., 1993), number of transferred queen cell cups (Van-Toor and Littlejohn, 1994 and Kutluca et al., 1998) gathering interim (Fiahinler and Fiahinler 2002), regardless of whether, the settlement is queenless or queenright (Van-Toor and Littlejohn, 1994). The royal jelly has three uses: feeding worker honeybee larvae, up to 90 hour of larval life; feeding of the queen during all its larval phase and adult life (Wang, 1965); and feeding of drone larvae during all its larval phase (Haydak, 1970).

\section{MATERIAL AND METHODS}

This experiment was conducted during the spring, summer and late summer season in 2015-2016 under the conditions of Kafr El-Sheikh governorate (with the facility of the agricultural research station in Sakha). 
The colonies of the experiment were equal strong prepared with 8 combs (brood, honey, pollen) cover with bees, 12 replicates were used in the experiment.

\section{Procedure:}

1. Exposing the breeding frames that carry the plastic cups to the breeding colony for two hours before the grafting. provide nutrition to the breeding colony

2. The one day larvae were transferred into the plastic cup by the grafting needle and then the breeding frame that carried three wooden par placed between the sealed brood comps.

3. Sugar solution with concentrate of $1 \mathrm{~kg}$ sugar: 1.5 litter water was used. Each colony fed on half a liter of the solution.

4. On the day following the grafting, we collect the number of acceptable royal cups and calculate the acceptance ratio.

5. On the same date of grafting, after 72 hours the breeding frames were raising from the breeding colonies and removing the larvae from the plastic cups by a Celestin needle. royal jelly was collected with a wooden spoon, and collecting the royal jelly according to the position of the cup on the bar (right, middle and left), according to the successful royal cups. The royal jelly containers were weighed empty and numbered with a code number. the capacity of each container was five grams. Each bar was weighed according to the cup's position (1-5 cup or less). The cups were divided by its number; the mean was calculated. The royal jelly was Saved in the fridge. The grafting process is repeated every three days. During the experiment, five grafting process were taken.

\section{RESULTS AND DISCUSSION}

\section{1- Effect of different batches within cub positions at different seasons.}

\section{1-1. Acceptance percentages:}

Data in Table (1) show the mean of the grafted queen cups acceptance percentages under cups position and different patches during year seasons.

At spring season, the highest acceptance percentage means were recorded as $(80.7,80.2$ and $63.9 \%)$ in the anterior, medium, and posterior / third, second and first batches, respectively, while the lowest acceptance percentage means were $(52.1,64.9$ and 66.8) recorded in the posterior, medium and anterior / fifth batch, respectively.

At summer season, the highest acceptance percentage means were (75.6, 67.7 and $57.1 \%$ ) recorded in the medium, anterior, and posterior / first, fourth, and first batches, respectively. while the lowest acceptance percentage means were $(52.1,63.3$ and 67.8) recorded in the posterior, anterior and medium / fifth, second and fifth batches, respectively.

At late summer season, the highest acceptance percentage means were (53.8, 53.8 and $41.8 \%$ ) recorded in the anterior, medium, and posterior / third, third and second batches, respectively. while the lowest acceptance percentage means were $(32.7, \quad 39.5$ and 45.1) recorded in the posterior, medium and anterior / fifth batch, respectively.

From the obtained results it could be concluded that the medium cubs had high acceptance percentages compared with the other position cups, furthermore, statistical analysis of the obtained data showed high significant differences between all treatments of the cup positions. 


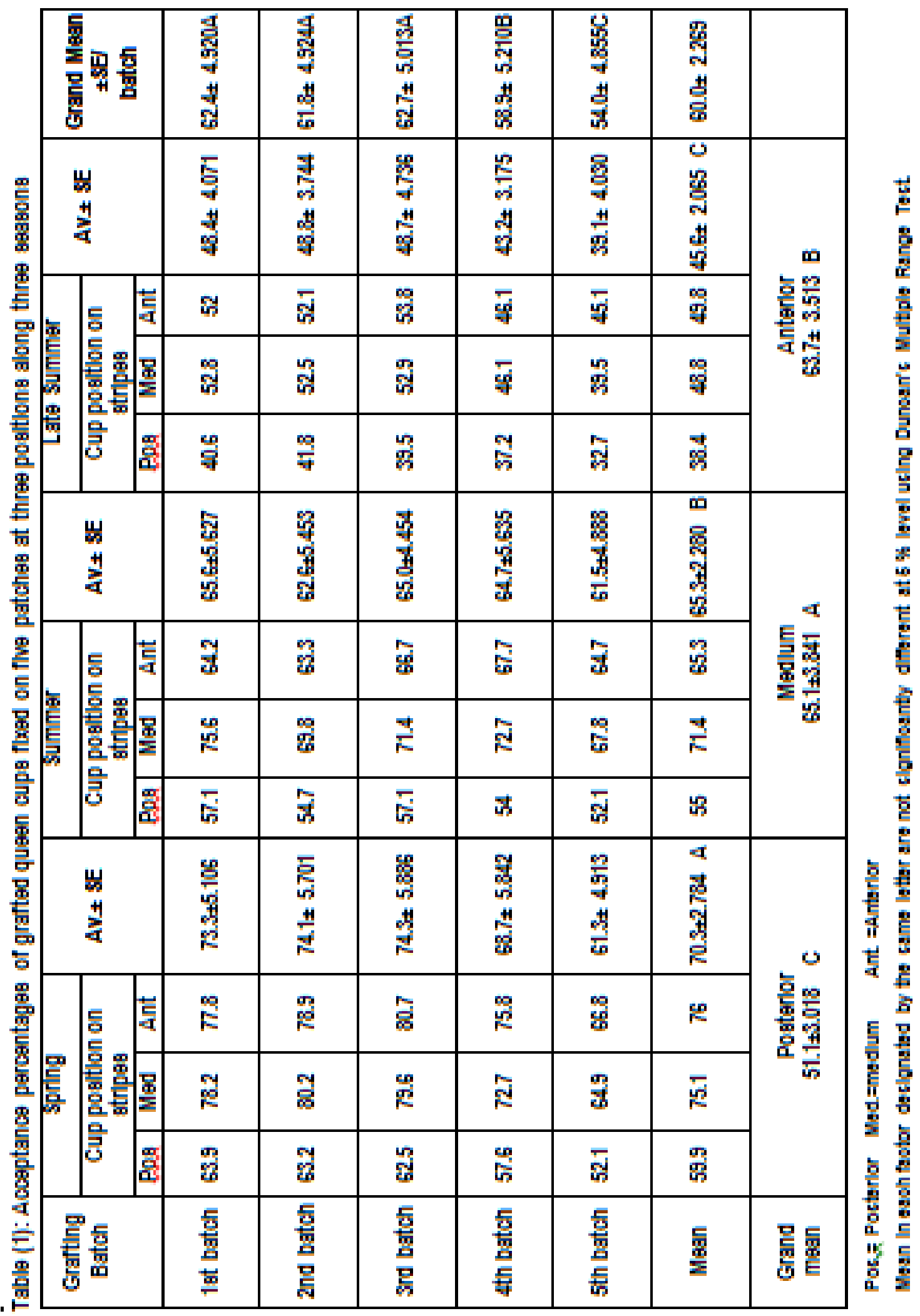


Date showed that the highest mean of acceptance percentages was recorded at the spring season, followed by summer and late summer, respectively. The statistical analysis of the data indicated that there were significant differences between the compared seasons.

Moreover, the third batches recorded the highest mean of cup acceptance percentages, followed by first batches, but the lowest one was in fifth batches. Statistical analysis of the data indicated that no significant differences between first/second/third batches, but there are significant differences between fourth, fifth and other batches.

Many researchers had discussed these findings and found that, Royal jelly is being produced as a result of grafting process and the acceptance of grafted queen cups is being affected by type of nutrition and queen cups introduced to the bees (Mohanny, 1999) and (Zeedan, 2002). In addition, acceptance percentage of queen cell was significantly higher when the grafted larvae were less than 48 hrs old (Abd Al-Fattah et al., 2003).

\section{1-2. The royal jelly production:}

Data in Table (2) show means of the royal jelly quantity (mg/cup) from different seasons as affected by cups position and grafting batches.

At spring season, the highest means of the royal jelly weights were (175.3, 173.3 and $149.2 \mathrm{mg} /$ cup) recorded in the anterior, medium, and posterior at the second batch, respectively. While, the lowest means of the royal jelly weights were $(134.7,158.8$ and $159.5 \mathrm{mg} /$ cup) recorded in the posterior, medium and anterior at the fifth batch, respectively.

At summer season, the highest means of the royal jelly weights were (162.5, 157.2 and $145.5 \mathrm{mg} / \mathrm{cup}$ ) recorded in the medium, anterior, and posterior at the third and fourth batches, respectively.
While, the lowest means of the royal jelly weights were (123.7, 142.6 and 144.3 $\mathrm{mg} /$ cup) recorded in the posterior, anterior and medium at the first and second patches, respectively.

At late summer season, the highest means of the royal jelly weights were (152.1, 151.5 and $124.7 \mathrm{mg} /$ cup) recorded in the medium, anterior, and posterior second batches respectively. While the lowest means of the royal jelly weights were (112, 128.3 and $137.5 \mathrm{mg} / \mathrm{cup}$ ) recorded in the posterior, medium and anterior at the fifth batch, respectively.

From the obtained results it could be concluded that the anterior cups have royal jelly weights more than the medium and posterior with significant differences between them. As the spring season, it showed the highest royal jelly weights followed by summer and late summer seasons, respectively with significant differences between them. However, the third batch showed the highest royal jelly weights with significant differences between first/fourth, second, third and fifth patches respectively.

Many researchers had discussed these findings and found that, the majority of royal jelly producers harvest at the third day after grafting where the amount of royal jelly in queen cells reaches its peak (Lercker et al., 1984). In Egypt, (Khattab et al., 1998) reported that the worker larvae grafted at the age of $\mathbf{1 2}$ hours were more acceptable and the queen cells gave more royal jelly than older ones. The best time for collectting royal jelly from queen cells was 3 days after grafting process. They revealed that, quantities of royal jelly produced from 28 F1 Carniolian colonies which used for grafting of queen-cups was 6036.6 grams. In Egypt, (Saleh, 1999) pointed out that the Carniolian race was better than Italian race in royal jelly production. 
Factors affecting the acceptance of honeybee queen cups and royal jelly ..........

\begin{tabular}{|c|c|c|c|c|c|c|c|c|c|}
\hline 寻急 & 畓 & 骂 毞 & 要娄 & 骂电 & 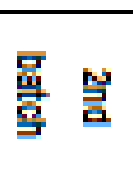 & 菐 & \multicolumn{3}{|c|}{ 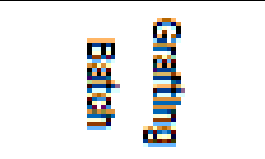 } \\
\hline \multirow{4}{*}{ 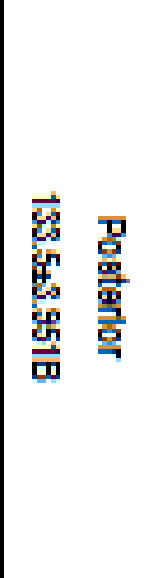 } & 点 & $\dot{E}$ & $\vec{B}$ & 要 & $\vec{b}$ & $\vec{k}$ & 䀄 & \multirow{3}{*}{ 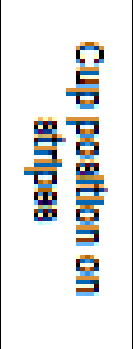 } & \multirow{3}{*}{ 煦 } \\
\hline & 票 & $\dot{y}$ & $\underline{\vec{p}}$ & \pm & $\vec{\Delta}$ & 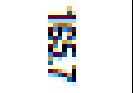 & 急 & & \\
\hline & 要 & 曷 & 离 & E & $\dot{\vec{H}}$ & 圖 & $\stackrel{5}{F}$ & & \\
\hline & 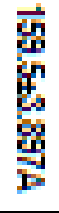 & 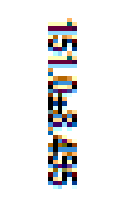 & $\stackrel{\vec{w}}{y}$ & 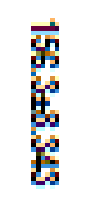 & 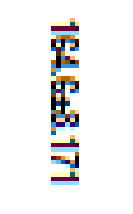 & 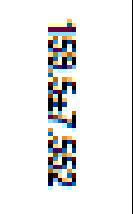 & \multicolumn{3}{|c|}{ 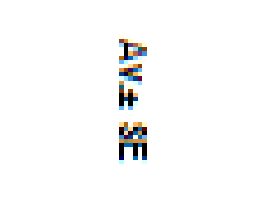 } \\
\hline \multirow{4}{*}{ 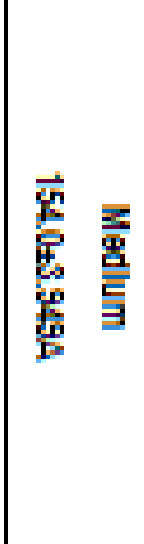 } & 복 & $\mathrm{E}$ & 忘 & \pm & $\vec{b}$ & $\overrightarrow{\mathrm{B}}$ & 盆 & \multirow{3}{*}{ 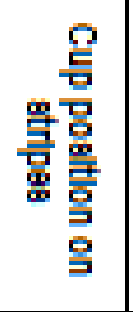 } & \multirow{3}{*}{ 韵 } \\
\hline & $\overrightarrow{\mathrm{H}}$ & $\vec{b}$ & 赑 & 覀 & $E$ & $\overrightarrow{\mathrm{G}}$ & 吾 & & \\
\hline & $\frac{\vec{H}}{\vec{b}}$ & 离 & 鸬 & $\vec{y}$ & 总 & $\overrightarrow{5}$ & 点 & & \\
\hline & 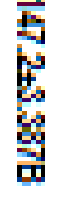 & $\begin{array}{l}5 \\
\mathrm{E}\end{array}$ & $\frac{\vec{\omega}}{\vec{t}}$ & 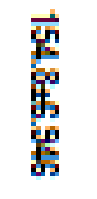 & 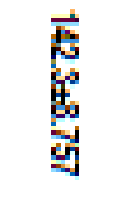 & 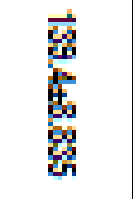 & \multicolumn{3}{|c|}{ 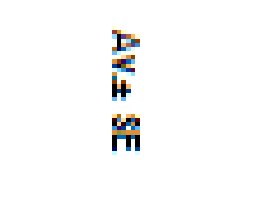 } \\
\hline \multirow{4}{*}{ 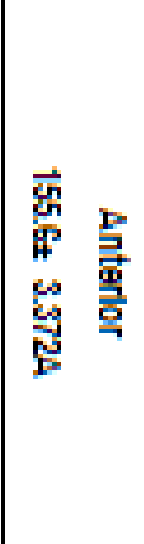 } & $\stackrel{\vec{E}}{\vec{E}}$ & $\overrightarrow{\bar{B}}$ & $\overrightarrow{\mathrm{B}}$ & 莺 & 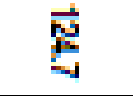 & $\overrightarrow{\bar{B}}$ & 㕝 & \multirow{3}{*}{ 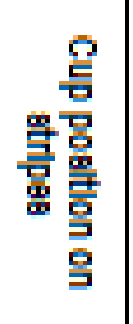 } & \multirow{3}{*}{$\begin{array}{l}\text { 혐 } \\
\text { 늘 } \\
\text { 극 }\end{array}$} \\
\hline & $\vec{b}$ & $\vec{B}$ & E & $\vec{b}$ & $\vec{\mu}$ & $\stackrel{5}{5}$ & 唔 & & \\
\hline & 点 & in & $\vec{b}$ & 焉 & 㟧 & 跑 & 当 & & \\
\hline & $\frac{9}{8}$ & 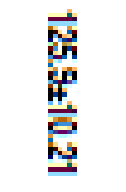 & 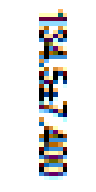 & 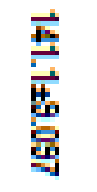 & 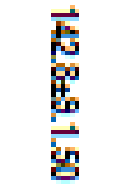 & $\frac{\overrightarrow{3}}{\overrightarrow{8}}$ & \multicolumn{3}{|c|}{ 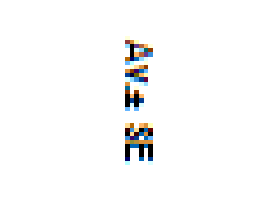 } \\
\hline & $\begin{array}{l}\overrightarrow{4} \\
\overrightarrow{\mathrm{E}}\end{array}$ & $\frac{\overrightarrow{5}}{\frac{5}{6}}$ & 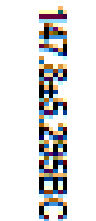 & $\begin{array}{l}\vec{g} \\
\text { 点 } \\
g\end{array}$ & 咅 & 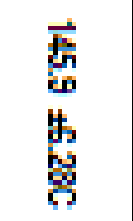 & \multicolumn{3}{|c|}{ 骂告畐 } \\
\hline
\end{tabular}




\section{REFERENCES}

Abd Al-Fattah, M., M. El-basiony and $\mathrm{H}$. Mahfouz (2003). "Some environmental factors affecting the quality of artificial reared queens,(Apis mellifera L.) in North Sinai region, Egypt." J. Agric. Sc. Mansoura Univ., 28 (8): 6407-6417.

Deseyn, J. and J. Billen (2005). Agedependent morphology and ultrastructure of the hypopharyngeal gland of Apis mellifera workers (Hymenoptera, Apidae). Apidologie, 36 (1): 49-57.

fiahinler, N. and S. Fiahinler (2002). Effects of The Number of Queen Cells and Harvesting Interval On the Acceptance Rates of the Larvae, Royal Jelly Quality and Quantity. J. Anim. Vet. Advan., 3: 120-122.

Fuhai, L., C. Shibi, H. Shengming and L. Fuxiu (1993). The Study on Pollen Substitutes of Honeybees. Honeybee, Royal jelly, Environment, Edited Dept. of Beekeeping Technology, Bee Inst. CAAS, Beijing, China. 22-40.

Hassan, R. E. and A. M. Khater (2006). Influence of pollen substitutes on longevity and hypopharyngeal glands of caged honey bee workers (Apis mellifera L.). J. Agric. Sci., Mansoura Univ., 31 (1): 419-427.

Haydak, M. H. (1970). Honey bee nutrition. Ann. Rev. Entomol., 15: 143156.

Howe, S. R., P. S. Dimick and A. W. Benton (1985). Composition of freshly harvested and commercial royal jelly. J. Agric. Res., 24: 52-61.

Khattab, M. M., M. A. El-samny, A. A. Elberry and S. I. Kassem (1998). Some factors affecting the commercial scale production of royal jelly secreted by honey bee (Apis mellefera L.) in Egypt.Annals of Agricultural Science, Moshtohor, 36 (3): 1959-1967.

Krell, R. (1996). Value-added products from beekeeping, Food \& Agriculture Org.

Kutluca, S., F. Genç and A. Dodologlu (1998). Besleyici kolonilere verilen ana arı yüksüklerinin sayısı ile hasat aralığının kolonilerin arı sütü verimine etkisi. Tr J. of Veterinary and Animal Sciences. 22: 363-369.

Lercker, G., M.A. Vecchi, L. Piana, A. Nanetti and A.G. Sabatini (1984). Composition de la fraction lipidique de la gelée royale de larves d'abeilles reines et ouvrières (Apis mellifera ligustica, Spinola) en fonction de l'âge des larves. Apidologie. 15, 303-314.

Mohanny, K. M. (1999). New treatments for increasing and improving the production of the honeybee colonies. Unpublished M. Sc. Thesis, Fayoum, Cairo Univ., 101 pp.

Nagai, Takeshi and Inoue, Reiji (2004). Preparation and the functional properties of water extract and alkaline extract of royal jelly. Food chemistry. 84 (2): 181-186

Sahinler, N., O. Kaftanoglo, A. Mizrahi and Y. Lensky (1997). Effect of feeding, age of larvae and queenless on the production of royal jelly, bee products, properties. Applications and Apitherapy, 35: 173-178.

Saleh, E. A. M. (1999). Comparative study on the royal jelly in the 1st hybrid colonies of some bee races under the local environmental conditions. Unpublished M.Sc. Thesis, Al-Azhar Univ., Egypt, 184 pp.

Schmidt, J. O. (1997). Bee products. Bee Products, Springer: 15-26.

Van-Toor, R. F. and R. Littlejohn (1994). Evaluation of hive management techniques in production of royal jelly by honey bees (Apis mellifera) in New Zealand. J. Apic. Res., 33(3): 160-166.

Wang, D. (1965). Growth rates of young queen and worker-honeybee larvae. J. Apic. Res., 4: 3-5.

Zeedan, E. (2002). "Studies on certain factors affecting production and quality of queen honeybees (Apis mellifera L.) in Giza region." Unpublished M. Sc. Thesis, Cairo Univ., 134 pp. 
العوامل المؤثرة على قبول كؤوس ملكات نحل العل وإنتاج الغذاء الملكي

أثرف شريف فتحي ، مروه بسيوني جمعة ، قطب إبراهيم هلالي

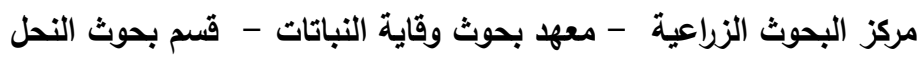

الملخص العربى

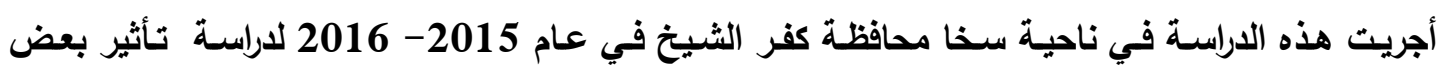

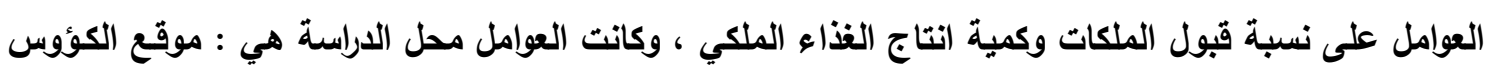

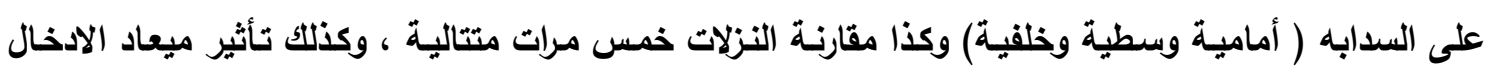

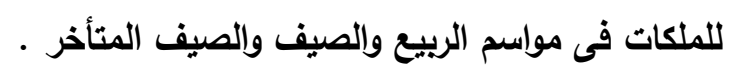

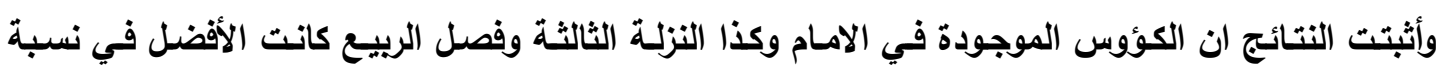
القبول للملكات وكذلك في كمية انتاج الغذاء الملكي يالمقارنة بالمعاملات الاخرى. 
A. S. F. Sherif, et al., 